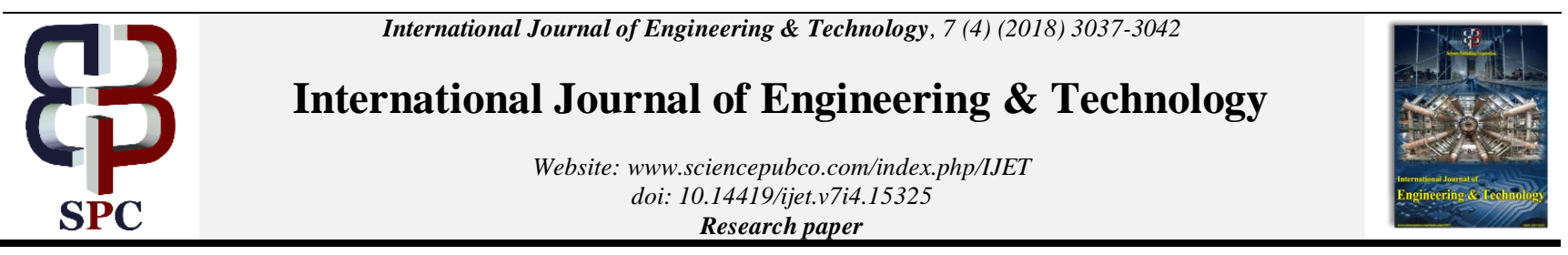

\title{
Study the microstructure and mechanical properties of dissimilar friction stir spot welding of carbon steel 1006 to aluminum alloy aa2024-t3
}

\author{
Isam Tareq Abdullah $^{1}$ *, Zaman Khalil Ibrahim ${ }^{2}$, Ahmed Ibrahim Razooqi ${ }^{3}$ \\ ${ }^{1,3}$ Middle Technical University/Engineering Technical Collage /Baghdad \\ ${ }^{2}$ Middle Technical University/Technical Institute/Kut \\ *Corresponding author E-mail: isamtareq@yahoo.com
}

\begin{abstract}
Friction stir spot welding-FSSW has been suggested as effectual process to welding difficult materials such as dissimilar materials and thin sheet of metal alloys. In this study, using dissimilar materials were welded carbon steel-1006 on upper plate and aluminum alloy AA2024-T3 on lower plate. Macrostructure, micro-structural analysis and mechanical properties of the joints are done. The effect of penetration depth, dwell time and spindle speed on tensile shear load are investigated with invariable of other parameter during welding process. The maximum tensile shear load $(3.31 \mathrm{KN})$ was occurred when using $0.4 \mathrm{~mm}$ of penetration depth, 10 sec of dwell time and 1400 rpm of spindle speed. Also, two type of failure shape was observed interfacial fracture of carbon steel sheet and pull-out fracture of AA2024-T3 sheet.
\end{abstract}

Keywords: Dissimilar Materials; Friction Stir Spot Welding; Carbon Steel; Aluminum Alloy; Microstructure Analysis; Tensile Shear Load.

\section{Introduction}

The direction of automotive industries is to raise the use of lightweight material instead of conventional steel, but aluminum is cost and addition aluminum is lower mechanical properties than steel. So as, the joining steel with aluminum is good disbandment. The constituted method for welding steel is (RSW) resistance spot welding .Unfortunately, this method is un-suitable for welding steel and aluminum due to forming the porosity in the join [1] Lately, a new welding method called) FSSW) friction stir spot welding or (FSJ) friction spot joining has been pullulate. This method has many advantages such as joining of dissimilar materials ease of handling, low distortion, materials that are difficult to fusion weld and excellent mechanical properties [2-3].

Friction stir spot welding (FSSW (process was first invented and developed by Mazda Motor Corporation (M.M.C) and Kawasaki Heavy Industry (K.H.I), patented in 2003 [4-5].

FSSW is a solid state joining method, the part or sample doesn't melt during welding, this method is a very important and novel variant of the linear friction stir welding (FSW) [5-6] Friction stir spot welding (FSSW) is a very important and novel variant of the linear friction stir welding (FSW ،(which gives higher potential to be a replacement of single point joining processes such as riveting and resistance spot welding. There have been many reports and wider applications about FSSW in aviation, automobile and aerospace fields.

The Friction stir spot welding method consists of [3] stages: plunging, stirring, and drawing out, as shown in figure [1]

The FSSW technique starts when the tool spinning at a constant speed. After that, the tool plunges into work-pieces even the tool shoulder contacts the weld surface. The plunging movement of the tool caused displacement of materials. Then plunging, the stirring stage starts when tool reaches a desired depth .In this stage, the tool keeps rotating into work-pieces, the frictional heat is generated in the contact and penetrating stages, in this time the materials around and underneath the tool are heated, softened, and mixed where solid state joint will be formed. When a joint is obtained, the tool is retracted from the work pieces. When a welding is happened, the tool is draw out from the work-pieces. This welding process shows as a keyhole in the middle, which decreases the mechanical properties of the welding. 3 distinctive regions were noted in FSSW process: (TMAZ) thermomechanical affected zone, (HAZ) heat affected zone and (SZ) the stir zone [6], [7]. as shown in figure $(2$.

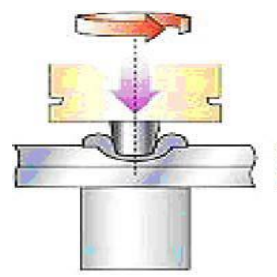

Plunging

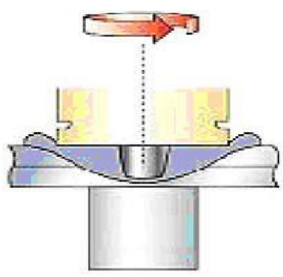

Stirring

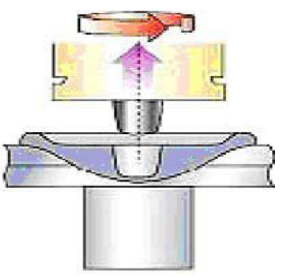

Drawing out Fig. 1: Schematic Illustration of (FSSW) Method [8].

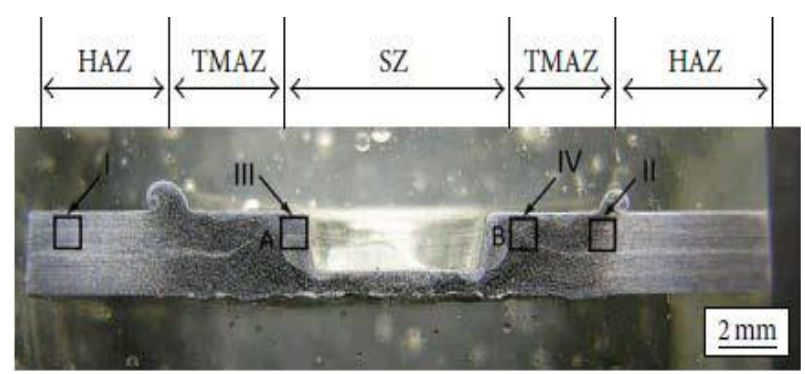


Fig. 2: Picture of Micrograph for the Cross Section of (FSSW) [6]

The friction spot join method takes up between 2 to $5 \mathrm{sec}$, this short time enough to generate of heat and formation of stir zone lead to create a weld between the 2 contacting sheets. Notice high peak temperatures gave a good contact interface between the adjacent material and rotating pin within the stir zone [9]

The basic difference between a conventional welding process and the solid-state welding is that there is no melt of the work-sheet in solid state welding method. It has many benefits of this method such as weight reduction, cost savings, low maintenance, better work environment recyclability and high consistence compared to other $\mathrm{Al}$ spot welding processes such as riveting and (RSW)resistance spot welding. Friction stir spot welding of higher-melt metals and alloys, including aluminum, stainless steel, steels ‘titanium and nickel are quite a few successful applications of friction stir welding [2].

The welding of steel and aluminum is become a prime research subject for automobile industry because of modern demands for light weight hybrid designs, high strength, corrosion resistance and improved crash properties. The welding technologies of these two materials are perfectly limited by their different chemical and physical properties. So that the avoid brittle intermetallic phases between $(\mathrm{Fe}+\mathrm{Al})$, the problem of formation of thick and to avoid the different melting points of materials radhesive joining is the main used welding technology for these types of joints in manufacturing process. Friction stir spot welding process provides by best durability and results [10].

K. O. Sanusi et al. in (2017 (evaluated the material characterization of dissimilar (FSSW) process between $\mathrm{Al}$ and $\mathrm{Cu}$ alloy. The condition of this process $(800 \mathrm{rpm})$ of rotational speed $(50,150$, 250) $\mathrm{mm} / \mathrm{min}$ of transverse speeds and the total number of specimens used was 9 altogether. The spot welds were characterized by using (SEM)scanning electron microscopy and (OEM)optical microscope. In addition of microstructure cross-section of the weld, the shear test of the spot welding was done. Show from results the welding between metals and alloys was successful by used FSSW and can be used in the many application of manufacturing [11].

E. Fereiduni et al. in (2015 (studied the effect of the dwell time and rotational speed on microstructure and mechanical properties of friction stir spot welded aluminum alloy AA5083 and 12 steel alloy sheets, it was taken the dwell time (from 5 to $15 \mathrm{sec}$ ) for the both rotation tool speed $(900,1100$ r.p.m) and found the optimum condition when using (900 r.p.m, $12 \mathrm{sec}$ ) reached to the max. failure load of $4020 \mathrm{~N}$ [12].

T. Liyanage et al. in (2014) investigated spot joining between AA6111 / low carbon steel sheets by using pin penetration depth of $0.4 \mathrm{~mm}$, plunge rate of $1 \mathrm{~mm} / \mathrm{sec}$ and tool rotational speed of 3000 r.p.m. Although AA6111with low carbon steel dissimilar joints friction spot welding overcame the failure strength properties needed resistance friction stir spot welding of aluminum alloy as base material, the intermetallic phases and the finding many of cracks lead to impact toughness properties and poor ductility [13]. G. Figner et al. in (2013) examined the dissimilar friction stir spot welding (FSSW) of aluminum alloy AA5754 with 4alvanized steel HX 340LAD. Specimen were produced for mechanical properties testing using a spindle Speeds range of 800-3 $200 \mathrm{rpm}$, dwell times range of $0-8 \mathrm{sec}$, but the plunge depth $2.2 \mathrm{~mm}$ and plunge rate $(12 \mathrm{~mm} / \mathrm{min})$ were constant for all welding. Concluded the maximum tensile shear strength was $8.3 \mathrm{kN}$ at $3 \mathrm{sec}$ and 3200 rpm [10.[

H. Liu et al. in (2013) studied the friction stir spot welding of (2A12-T4) aluminum alloy and investigated mechanical properties and micro-structural characteristics of this joint. Found a softened micro-structural area found in the joint, and it consisted of (SZ) stir-zone, (TMAZ)thermal mechanically affected -zone and (HAZ)heat affected-zone, also record minimum value of hardness in the region of TMAZ and the maximum of hardness in the region of SZ because increasing welding heat input. The tensile shear load of the weld increased with increasing rotation of tool speed, but it decreased with decreasing shoulder plunging depth or increasing plunge rate [14].

Sun et al. in (2013) welded AA6061-T6 with mild steel sheets at $(1 \mathrm{~mm})$ of thickness by using friction spot welding process. They estimated that the ideal dwell time and rotational speed were and 2second and $700 \mathrm{rpm}$, respectively, when used 3 different pin lengths $(1,1.3$ and 1.5$) \mathrm{mm}$ to join the specimen .The max. tensile shear strength $(3200 \mathrm{~N})$ was achieved for the tool at $(1 \mathrm{~mm})$ pin length at the ideal rotational speed and dwell time.

Adding that the results seen no notice intermetallic layer found along welding between $\mathrm{Al}$ alloy and steel. .[10]

Y.C. Chen et al. in (2012) welded Aluminum alloy (6111-T4) and steel alloy (DC04) sheets by friction stir spot process and changed these parameters weld times from $0.5-18$ second, welding speed from 60 to $2000 \mathrm{~mm} / \mathrm{min}$, but some of parameters were fixed in experiments such as plunge depth of $0.1 \mathrm{~mm}$ and a low rotation speed $800 \mathrm{rpm}$ to reduce the heat input. The maximum fracture energy of $6.5 \mathrm{kN} . \mathrm{mm}$ and maximum failure load of $3.5 \mathrm{kN}$ was obtained with weld time of only 1.1 second, welding speed of 1 $\mathrm{m} / \mathrm{min}[16]$.

E .Taban et al. in (2009) joined between $\mathrm{Al}$ alloy (6061-T6) and steel (AISI 1018) by using friction spot welding with many parameters and this welding evaluated by metallurgical analysis such as micro-structural and (SEM) scanning electron microscopy, also mechanical testing such as micro-hardness . Results of these tests provide the failures were seen on the aluminum side in the plasticized layer of the joint. Further, bond lines were seen by a thin layer of formed $\mathrm{Al}-\mathrm{Fe}$ inter-metallic [17].

C. Y. Lee et al. in (2009) used dissimilar welding of low carbon steel and $\mathrm{Al}-\mathrm{Mg}$ alloy were happened by (FSSW). These joining conditions get it possible to weld steel plate by using welding tools manufacturing from tool steel and increased depth of penetration tool. Maximum value of tensile shear force was $3 \mathrm{kN}$, when depth of penetration tool was $0.5 \mathrm{~mm}$, if the depth of penetration tool higher than $0.5 \mathrm{~mm}$ that lead to deformation of Aluminum sheet of top side. In the result of interface observation and formation strongly interaction layer between steel and aluminum alloy [18].

The aim of this search checking the ability of join the different sheet metals such as (carbon steel with Aluminum) by new process friction stir spot welding. To make sure this welding finish successfully we must observe microstructure and inspect the mechanical properties for welding specimens. After that estimate the optimum condition for friction stir spot welding process.

\section{Experimental work}

\subsection{Materials used}

Mild carbon steel (1006-AISI) and aluminum alloy (AA2024-T3) sheets were used for this present work as shown in the figure (3). The dimension of first material was $100 \times 25 \times 0.8 \mathrm{~mm}$ of mild carbon steel (1006-AISI) and the dimension of second material was $100 \times 25 \times 1.1 \mathrm{~mm}$ of aluminum alloy AA2024-T3, the lap welded with steel sheet on the top.

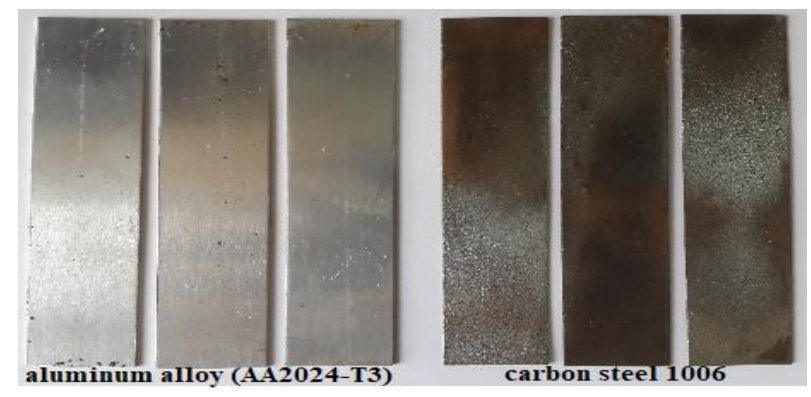

Fig. 3: Sheets Preparation for Welding.

All the welded specimens were comprised of two $100 \mathrm{~mm} \times 25$ $\mathrm{mm}$ sheets (parallel to the rolling direction) with an overlap area 
of $25 \mathrm{~mm}$ by $25 \mathrm{~mm}$, which were welded in the center of the overlap area.

The following tables (1) and (2) shown actual chemical compositions of the materials used. These alloys were analyzed to find their actual chemical compositions in the Central Organization for
Standardization and Quality Control in Baghdad and compared with their standard values [19]. The mechanical properties of two materials are presented in tables (3) and (4).

Table 1: Actual Chemical Composition of Mild Carbon Steel 1006- AISI

\begin{tabular}{|c|c|c|c|c|c|c|c|c|c|c|}
\hline Element wt $\%$ & & $\mathrm{C}$ & $\mathrm{Mn}$ & $\mathrm{P}$ & & $S$ & $\mathrm{Cr}$ & $\mathrm{Ni}$ & Mo & $\mathrm{Cu}$ \\
\hline Measured & & 0.062 & 0.169 & 0.016 & & 0.006 & 0.055 & 0.035 & 0.002 & 0.006 \\
\hline Element wt\% & $\mathrm{Si}$ & $\mathrm{Fe}$ & $\mathrm{Cu}$ & $\mathrm{Mn}$ & $\mathrm{Mg}$ & $\mathrm{Cr}$ & $\mathrm{Zn}$ & $\mathrm{Ti}$ & $\mathrm{Ti}+\mathrm{Zr}$ & $\mathrm{Al}$ \\
\hline Measured & 0.09 & 0.22 & 4.7 & 0.58 & 1.4 & 0.04 & 0.1 & 0.01 & 0.01 & Balance \\
\hline
\end{tabular}

Table 3: Actual Mechanical Properties of Mild Carbon Steel

\begin{tabular}{lcc} 
& Table 3: Actual Mechanical Properties of Mild Carbon Steel \\
\hline Property & $\sigma u(\mathrm{MPa})$ & $\sigma \mathrm{MPa})$ \\
\hline Measured & 229.12 & 127.7 \\
\hline
\end{tabular}

Table 4: Actual Mechanical Properties of AA2024-T3 Aluminum Alloy

\begin{tabular}{lll}
\hline Property & $\sigma \mathrm{u}(\mathrm{MPa})$ & $\sigma \mathrm{y}(\mathrm{MPa})$ \\
\hline Measured & 449.2 & 329.5 \\
\hline & & \\
\cline { 2 - 3 }
\end{tabular}

\subsection{Specimen preparation}

Each sample was prepared by cutting sheets in the dimensions: Length $(\mathrm{L})=100 \mathrm{~mm}$ and Width $(\mathrm{W})=25 \mathrm{~mm}$, according to American Welding Society (AWS) resistance welding handbook [20].

The overlap spot joint alignment and dimensions are shown in table (5) and figure (4). The overlap joint sample has dimensions of $25 \mathrm{~mm}$ wide

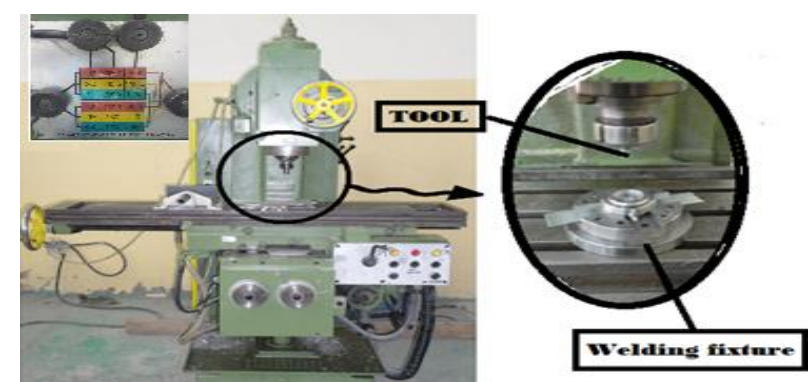

Fig. 5: Vertical Milling Machine Used to Achieve the Spot Welding.

In addition, $175 \mathrm{~mm}$ length.

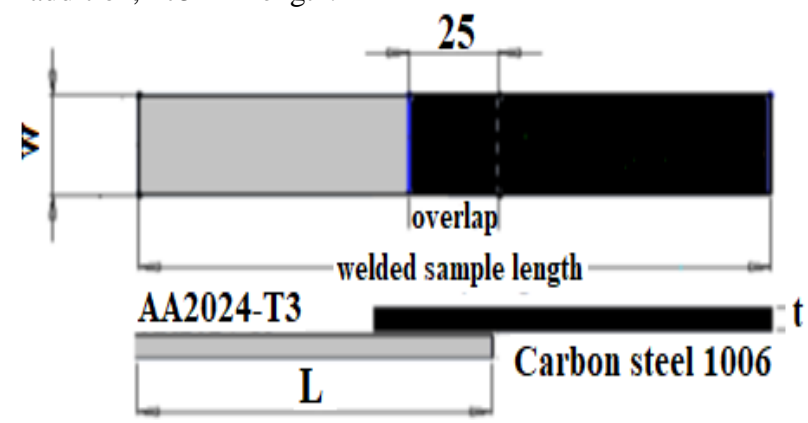

Fig. 4: Overlapping of FSSW Sample All Dimensions in Mm.

Table 5: Dimensions of Welded Samples.

\begin{tabular}{lllll}
\multicolumn{5}{c}{ Table 5: Dimensions of Welded Samples. } \\
\hline Type of material & $\begin{array}{l}\text { Thickness } \\
\text { (t) } \mathrm{mm}\end{array}$ & $\begin{array}{l}\text { Width } \\
\text { (W) } \mathrm{mm}\end{array}$ & $\begin{array}{l}\text { Length (L) } \\
\mathrm{mm}\end{array}$ & $\begin{array}{l}\text { Contact } \\
\text { overlap } \\
\text { mm }\end{array}$ \\
\hline AA2024-T3 & 1.1 & $25 \mathrm{~mm}$ & $100 \mathrm{~mm}$ & $25 \mathrm{~mm}$ \\
$\begin{array}{l}\text { Carbon steel } \\
\text { (1006-AISI) }\end{array}$ & 0.8 & $25 \mathrm{~mm}$ & $100 \mathrm{~mm}$ & $25 \mathrm{~mm}$ \\
\hline
\end{tabular}

Table 6: Parameters of Friction Stir Spot Welding For Carbon Steel and AA2024-T3

\begin{tabular}{llll}
\hline $\begin{array}{l}\text { Rotation speed } \\
(\mathrm{rpm})\end{array}$ & $\begin{array}{l}\text { Feed rate } \\
(\mathrm{mm} / \mathrm{min})\end{array}$ & $\begin{array}{l}\text { Preheat (dwell } \\
\text { time) second }\end{array}$ & $\begin{array}{l}\text { Depth } \\
\mathrm{mm}\end{array}$ \\
\hline 1800,1400, & 16 & 10,15 & 0.2, \\
\hline
\end{tabular}

\subsection{Friction stir spot welding (FSSW) technique}

A vertical universal milling machine was used shown in figure (5) for FSSW experiments of mild carbon steel and AA2024-T3. The important properties of universal milling machine, as Spindle rotation speed range from $(35.5-1800 \mathrm{rpm})$, Spindle power is 4.5 $\mathrm{kW}$ and Feed rates $(16-800 \mathrm{~mm} / \mathrm{min})$. The milling machine was used with variable rotation speeds from (1800-710 rpm). Using tungsten carbide tool in this study have $10 \mathrm{~mm}$ diameter. A key geometrical feature of the tool is shown in figure (6), the tool was held by a standard tool holder. The welding parameters used to make the FSSW joints are presented in below table (6).

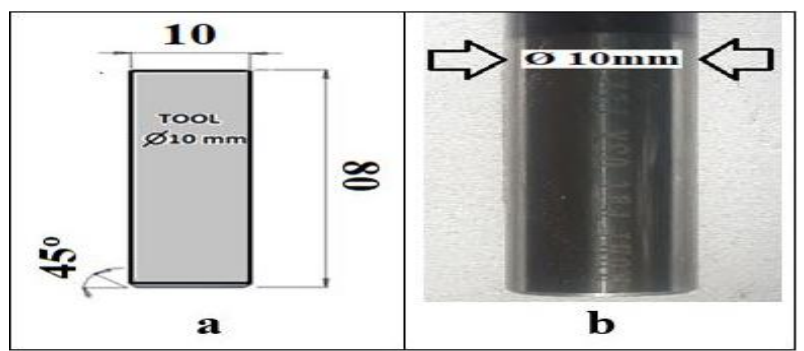

Fig. 6: Tool Geometrical Dimension, A) Tool Geometry B) Tool Photograph All Dimensions in Mm.

FSSW process procedure has been done in three stages:

- First stage, the pre- heating was achieved for each welded sample before the plunging step in order to generate the heat in samples, see figure (7-a).

- Second stage, the tool pin was plunged from upper, see figure (7-b).

- Third stage, the tool is removed easily; see Figure (7-c).
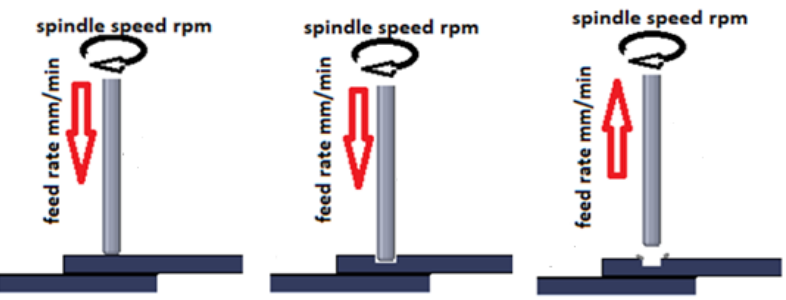

Fig. 7: Friction Stir Spot Welding (FSSW) Steps A-First Stage, B- Second Stage and C- Third Stage.

After that, welded all specimens in the same of condition and dimension above, the final shape of specimens as seen in the figure (8). 


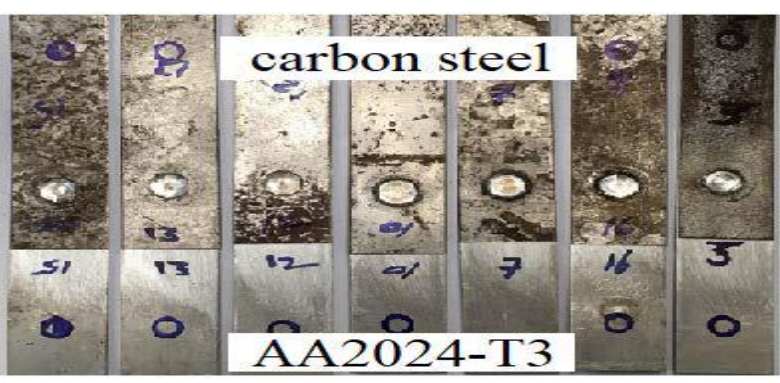

Fig.8: Samples of Welded Specimens.

\section{Results and discussion}

\subsection{Weld appearance}

The macro-photo of the joint is shown in figure (9), it shown the cross section of the spot and interface region between dissimilar metals. When, used carbon steel for upper sheet and aluminum alloy for lower sheet that lead to need high power to joining two plats, but this joined was too strong because the carbon-steel was hardly ever deformed because the melting temperature of aluminum is lower than that of carbon-steel. the weld flash 'Therefore [r $[$ l ] consists at the interface
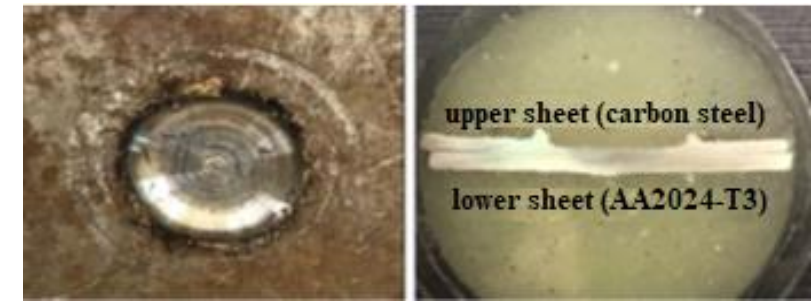

Fig. 9: Macrostructure Photographs of Cross-Section of Dissimilar FSSW Joints.

\subsection{Microstructure analysis}

The microstructures analysis was performed to examine the integrity of the welded joints. Figure (10) show the results of microstructures analysis for Carbon Steel -1006 to Aluminum Alloy AA2024-T3 welded by FSSW process.

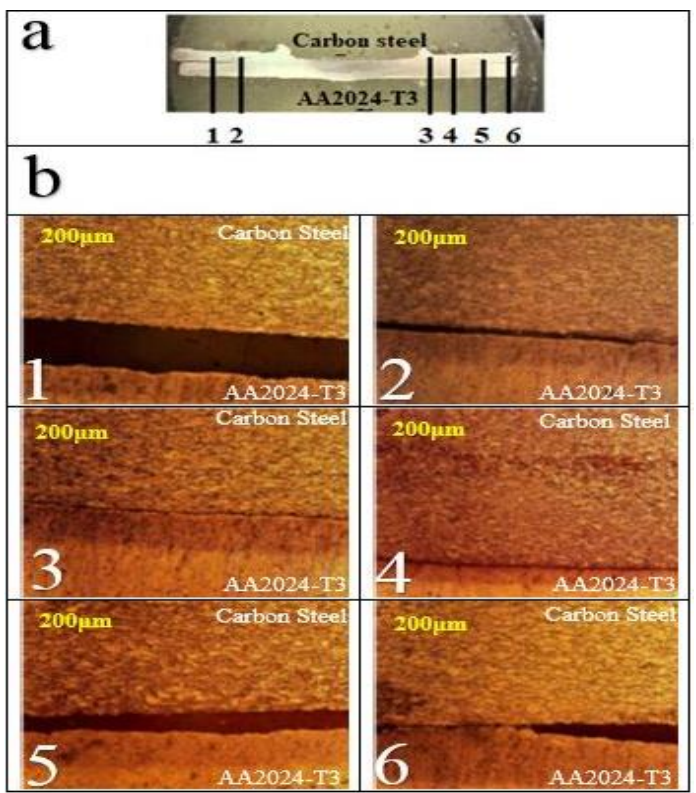

Fig. 10: Microstructures of the Cross-Section of Friction Stir Spot Welds for Different Regions at Spindle Speed (1400 Rpm), Feed Rate (16mm/Min), Depth of Tool (0.4mm) And Dwell Time (10sec): A) Cross Section of Weld Zone, B) Magnified Views of the Regions Respectively.
They observed that the defects were appeared at the edge of the welded sample which may come from the wears from the tools [2] and the microstructures of the joints varied significantly depending on the tensile shear strength, dwell time and tool rotational speed [8].

In the weld zone notice that no evidence of melted material and the other hand the microstructure was not deformed in the Fe plate side [18]. The interface between $\mathrm{Fe}$ and $\mathrm{Al}$ sheets at the weld was investigated as show in the microstructure results.

\subsection{Tensile shear strength results}

A according the results below, the value of tensile shear load depending on many variables such as penetration depth ( $\mathrm{mm})$, spindle speed (rpm) and dwell time ( $\mathrm{sec})$. The average tensile shear loads of the samples welded at different parameters process conditions are shown in table (7).

Table 7: Tensile Shear Strength Values of Carbon Steel -1006 to AA2024T3

\begin{tabular}{|c|c|c|c|c|c|}
\hline $\begin{array}{l}\text { Spindle } \\
\text { rpm speed }\end{array}$ & $\begin{array}{l}\text { Feed rate } \\
\mathrm{mm} / \mathrm{min}\end{array}$ & $\begin{array}{l}\text { Preheat } \\
\text { (dwell time) } \\
\text { second }\end{array}$ & $\begin{array}{l}\text { Exp } \\
\text { No }\end{array}$ & $\begin{array}{l}\text { Depth } \\
\text { mm }\end{array}$ & $\begin{array}{l}\text { Tensile } \\
\text { shear test } \\
\text { KN }\end{array}$ \\
\hline \multirow{4}{*}{$1 \wedge \ldots$} & \multirow{4}{*}{17} & -With pre & 1 & 0.2 & 1.71 \\
\hline & & ) heat10( & 2 & 0.4 & 2.98 \\
\hline & & -With pre & 3 & 0.2 & 0.65 \\
\hline & & ) heat15( & 4 & 0.4 & 1.16 \\
\hline \multirow{4}{*}{ VI. } & \multirow{4}{*}{17} & -With pre & 5 & 0.2 & 2.56 \\
\hline & & ) heat10( & 6 & 0.4 & 3.31 \\
\hline & & -With pre & 7 & 0.2 & 2.41 \\
\hline & & ) heat15( & 8 & 0.4 & 2.77 \\
\hline \multirow{4}{*}{ VI. } & \multirow{4}{*}{17} & -With pre & 9 & 0.2 & 1.98 \\
\hline & & ) heat10( & 10 & 0.4 & 2.81 \\
\hline & & -With pre & 11 & 0.2 & 0.81 \\
\hline & & ) heat15( & 12 & 0.4 & 1.12 \\
\hline \multirow{4}{*}{ VI. } & \multirow{4}{*}{17} & -With pre & 13 & 0.2 & 0.89 \\
\hline & & ) heat10( & 14 & 0.4 & 2.51 \\
\hline & & -With pre & 15 & 0.2 & 0.66 \\
\hline & & ) heat15( & 16 & 0.4 & 1.78 \\
\hline
\end{tabular}

\subsubsection{Effect of tool penetration depth and dwell time}

The tools were rotated at constant speed to occurring penetration and stir the materials to be welded. The work-piece (or specimen) is kept in a lap-configuration of FSSW. The penetration depth of tool in the upper plate in charge to decide the general quality of the welds. Also, the plunge depth in the lower plate and the thickness of upper and lower plates are other parameters can be considered [4].

The below Figures (11) and (12) seen the impact of tool depth and pre-heat time on average tensile shear test. The main effect of tool depth can be show, when used 0.2 and $0.4 \mathrm{~mm}$ with different spindle speed. Increasing the tool depth at constant dwell time leads to higher strength. This result was observed at different spindle speeds. This is clearly visible for 10 and 15 second preheat times. These results conform with [6].

Therefore, the using of tool depth $0.4 \mathrm{~mm}$ lead to increasing of failure load than tool depth $0.2 \mathrm{~mm}$ at constant dwell time $10 \mathrm{sec}$ approximately $65 \%$ at tool speed 710r.p.m ,30\% at tool speed 900r.p.m ,23\% at tool speed 1400r.p.m,43\% at tool speed 1800r.p.m.

The dwell time is called for the time duration when the tool stays contact with the work-piece during all stages (plunging, string and drawing out). From figure (11) and figure (12) can be concluded the shorter time lead to achieved the higher tensile shear load that mean to obtained super joint strengths by using short weld times. The tensile load improved by increasing dwell time to $10 \mathrm{sec}$, after that the joint strength decreased with increasing of the dwell time to $15 \mathrm{sec}$. The long dwell time caused the excess formation of inter-metallic layer. Also, some of the welds saw poor strength depending on some accrual of alloy elements at the interface, because the i.e Fe/Al [21]. 
Dwell time is proved has great influence on failure load followed by tool depth and tool rotation speed. These results conform with [4], [12] and [16.[

If compare between failure load when used dwell time(10sec) and failure load when used dwell time $(15 \mathrm{sec})$ at the same depth of tool $(0.4 \mathrm{~mm})$, which the failure load with dwell time $10 \mathrm{sec}$ increases approximately $29 \%$ at tool speed 710 r.p.m ,60\% at tool speed 900r.p.m , $16 \%$ at tool speed 1400r.p.m,61\% at tool speed 1800r.p.m.

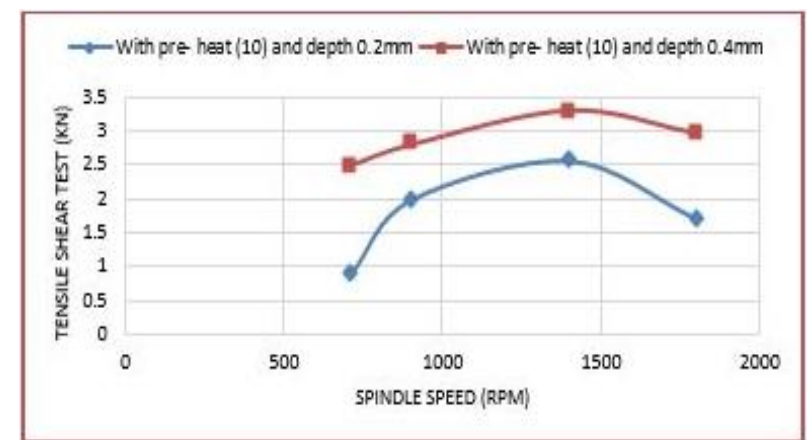

Fig. 11: Illustration Effect at Different Depth and Pre-Heat (10) Second on Tensile Shear Load.

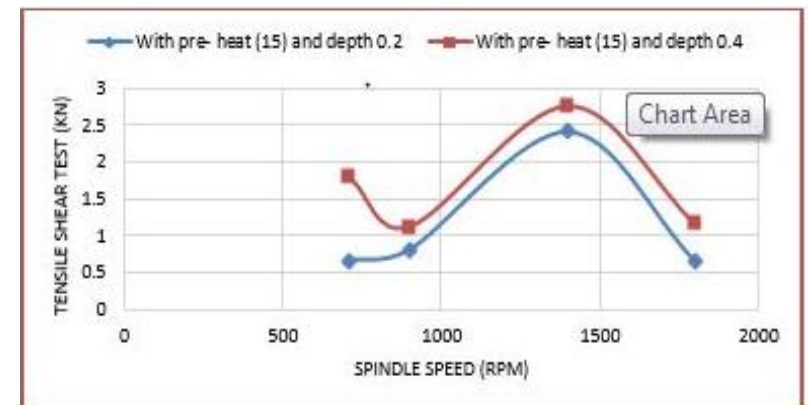

Fig. 12: Illustration Effect at Different Depth and Pre-Heat (15) Second on Tensile Shear Load.

\subsubsection{Effect of tool rotational speed}

To studding the effect of spindle speed (tool speed) on tensile shear strength of welding, all specimens welding were run out at the travels speed of $16 \mathrm{~mm} / \mathrm{min}$. The tool rotation speed was change from $710 \mathrm{rpm}$ to $1800 \mathrm{rpm}$. Figure (13) and (14) shows the spindle speed against average tensile shear load at different dwell time $(10,15 \mathrm{sec})$. For each parameter used, five specimens were tested, and the standard-deviation was usually less than $12 \%$ of the average load value. Increasing the spindle speed at constant dwell time leads to higher strength reach to 1400rpm spindle speed, after that the tensile load decrease when used $1800 \mathrm{rpm}$ spindle speed. Generally, this result was shown clearly visible for 10 and 15 second dwell times. These results conform with [10]. The maximum failure load was $3.31 \mathrm{KN}$ at spindle speed $1400 \mathrm{rpm}$, penetration depth $0.4 \mathrm{~mm}$ and dwell time $10 \mathrm{sec}$.

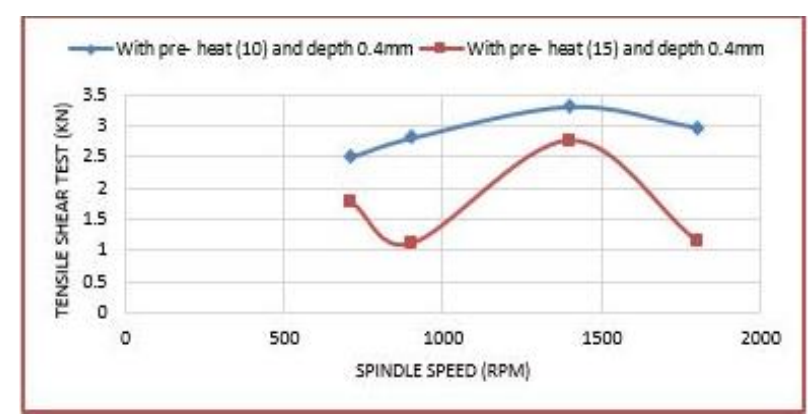

Fig. 13: Effect of Spindle Speed (Rpm) on the Tensile Shear Load at $0.4 \mathrm{~mm}$ Depth of Tool with Different Dwell Time.

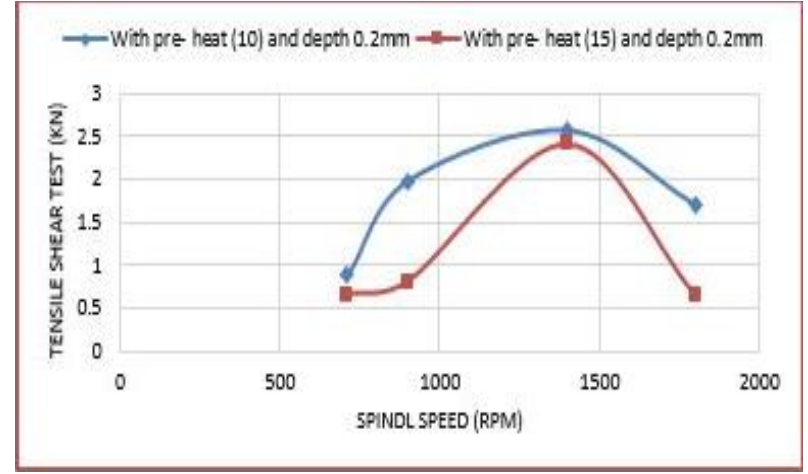

Fig. 14: Effect of Spindle Speed (Rpm) on the Tensile Shear Load at $0.2 \mathrm{~mm}$ Depth of Tool with Different Dwell Time.

\subsection{Failure mode}

Figure (15) shows the fracture mode of surface for the specimen of tensile shear tests. For all welds, the fracture taken at the steel/aluminum interface. Aluminum was found at the near of exithole for tool at the steel fracture surface.

The 2 main modes of failure for FSSW process are: interfacial and pullout fracture.

Pullout failures occurred because the emerging scant higher energy absorption leads to the larger displacement-prior to separation of these sheets.

The average fracture load for static-lap tensile shear tests of the nugget pullout mode is slight higher than the interfacial-fracture for dissimilar welds [10].
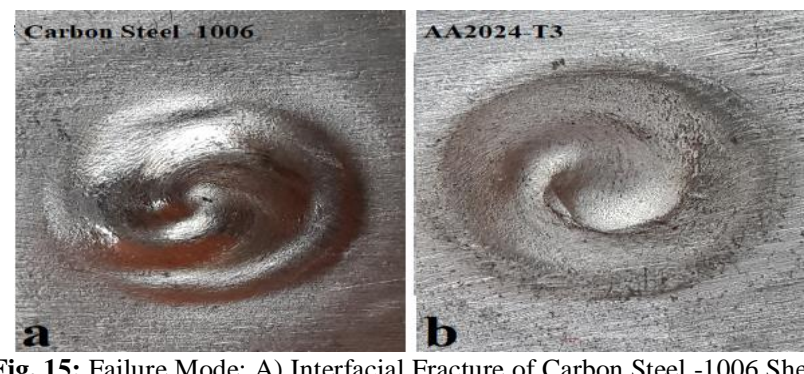

Fig. 15: Failure Mode: A) Interfacial Fracture of Carbon Steel -1006 Sheet B) Pull-Out Fracture of AA2024-T3 Sheet.

\section{Conclusion}

In this study, the carbon steel -1006 plate and aluminum alloy AA2024-T3plate were welded successfully. The friction stir spot welding process was investigated by macro -structural observation, microstructure analysis, shear tensile load and failure mode. As a result:

1) The uniform of macrostructure photographs of cross-section of dissimilar (steel/aluminum) for FSSW joints.

2) The fine grains size, uniformly distributed and very fine strengthening-precipitates in the weld zone were observed from microstructure analysis.

3) Many welding parameters such as, penetration depth (mm), dwell time (sec) and spindle speed (rpm), selected in the dissimilar FSSW to studying the effective.

4) The tensile shear load or failure load increasing with increase spindle speed until reach the maximum value $(3.31 \mathrm{KN})$, after that the failure load began to decrease.

5) For both of the applied depth of tool 0.2 and $0.4 \mathrm{~mm}$, the failure load first improved and then decreased with the increased dwell time $15 \mathrm{sec}$.

6) The best result of shear tensile load obtained when using high penetration depth of tool $0.4 \mathrm{~mm}$ for all condition because the high depth lead to stronger joints.

7) The optimum shear tensile load found with (1400rpm) spindle speed, $(0.4 \mathrm{~mm})$ depth of tool and $(10 \mathrm{sec})$ dwell time, when kept constant of feed rate $16 \mathrm{~mm} / \mathrm{min}$ at all condition. 
8) Two shape observing of failure mode: Interfacial fracture of Carbon Steel -1006 sheet and pullout fracture of AA2024$\mathrm{T} 3$ sheet.

\section{References}

[1] S. Bozzi, A.L. Helbert-Etter, T. Baudin, B. Criqui, J.G. Kerbiguet," Intermetallic Compounds in Al 6016/IF-Steel Friction Stir Spot Welds", Materials Science and Engineering A Vol. 527, pp 45054509, 2010. https://doi.org/10.1016/j.msea.2010.03.097.

[2] E. T. Akinlabi, Kazeem O, Sanusi, E. Muzenda, and S. A. Akinlabi," Material Behaviour Characterization of Friction Stir Spot Welding of Copper", Materials Today: Proceedings, Vol.4 pp166-177, 2017. https://doi.org/10.1016/j.matpr.2017.01.010.

[3] Y.Tozaki, Y. Uematsu, K. Tokaji,"Effect of Tool Geometry on Microstructure and Static Strength in Friction Stir Spot Welded Aluminium Alloys",International Journal of Machine Tools \& Manufacture,Vol. $\quad 47, \quad$ pp 2230-2236, 2007 https://doi.org/10.1016/j.ijmachtools.2007.07.005.

[4] S. Siddharth and Dr. T. Senthilkumar," Study of Friction Stir Spot Welding Process and its Parameters for Increasing Strength of Dissimilar Joints", Rev. Téc. Ing. Univ. Zulia., Vol. 39, No. 1, pp168 176, 2016.

[5] Assembly Magazine Available Online at https://www.assemblymag.com.

[6] X. W. Yang, T. Fu, and W. Y. Li," Friction Stir Spot Welding: A Review on Joint Macro- and Microstructure, Property, and Process Modeling" Advances in Materials Science and Engineering, Vol. 2014, Article ID 697170, 11 pages, 2014.

[7] Yuyang Chen, Refill Friction Stir Spot Welding of Dissimilar Alloys", thesis of master for University of Waterloo, Waterloo, Ontario, Canada, 2015.

[8] M. P. Mubiayi, Member, Iaeng and Esther T. Akinlabi," Friction Stir Spot Welding of Dissimilar Materials: An Overview", Proceedings of the World Congress on Engineering and Computer Science, Vol. II, pp 22-24, San Francisco, USA, October, 2014.

[9] P. SU, A. Gerlich, T.H. North, and G.J. Bendzsak," Intermixing in Dissimilar Friction Stir Spot Welds", The Minerals, Metals \& Materials Society and ASM International, Vol. 38A, March, 2007.

[10] G. Figner, R. Vallant, T. Weinberger, H. Schrottner, H. Pasic and N. Enzinger," Friction Stir Spot Welds between Aluminum and Steel Automotive Sheets: Influence of Welding Parameters on Mechanical Properties and Microstructure", ResearchGate, Welding in the World, https://doi.org/10.1007/BF03266697.

[11] K.O. Sanusi and E.T. Akinlabi," Material Characterization of Dissimilar Friction Stir Spot Welded Aluminium and Copper Alloy", Materials Science and Engineering, Vol. 225, 2017.

[12] E. Fereiduni, M. Movahedi and A.H. Kokabi," Aluminum/Steel Joints Made by an Alternative Friction Stir Spot Welding Process", Journal of Materials Processing Technology, Vol. 224, pp1-10, 2015. https://doi.org/10.1016/j.jmatprotec.2015.04.028.

[13] T. Liyanage, J. Kilbourne, A. P. Gerlich and T. H. North," Joint Formation in Dissimilar Al Alloy/Steel and Mg Alloy/Steel Friction Stir Spot Welds", ResearchGate, Science and Technology of Welding \& Joining, https://doi.org/10.1179/136217109X456960.

[14] H. Liu, Y. Zhao, X. Su, L. Yu, and J. Hou," Microstructural Characteristics and Mechanical Properties of Friction Stir Spot Welded 2A12-T4 Aluminum Alloy", Advances in Materials Science and Engineering, Article ID 719306, 10 pages, 2013.

[15] Sun, Y.F., Fujii, H., Takaki, N. and Okitsu, Y., "Microstructure and Mechanical Properties of Dissimilar Al Alloy/Steel Joints Prepared by a Flat Spot Friction Stir Welding Technique", Material Design,Vol. 47,pp 350-357, 2013. https://doi.org/10.1016/j.matdes.2012.12.007

[16] Y.C. Chen, A. Gholinia and P.B. Prangnell," Interface Structure and Bonding in Abrasion Circle Friction Stir Spot Welding: A Novel Approach for Rapid Welding Aluminum Alloy to Steel Automotive Sheet ", Materials Chemistry and Physics, Vol. 134, pp 459- 463, 2012 https://doi.org/10.1016/j.matchemphys.2012.03.017.

[17] E. Taban, J. E. Gould, J. C. Lippold," Dissimilar Friction Welding of 6061-T6 Aluminum and AISI 1018 Steel: Properties and Microstructural Characterization", Materials and Design, Vol.31, pp 2305-2311, 2010. https://doi.org/10.1016/j.matdes.2009.12.010

[18] C. Y. Lee, D. H. Choi, Y. M. Yeon and S. B. Jung," Dissimilar Friction Stir Spot Welding of Low Carbon Steel and Al-Mg Alloy by Formation of IMCs ", Science and Technology of Welding and Joining, Vol. 14, No.3, pp 216-220, 2009. https://doi.org/10.1179/136217109X400439.
[19] ASM Handbook, "Properties and Selection: Non-Ferrous Alloys and Special Purposes Materials", American Society for Metals, Vol. 2, (1992).

[20] American Welding Society," Resistance Welding Theory and Use", Reinhold Publishing Corporation New York, Chapman \& Hall, LTD, London 1956.

[21] Mumin Sahin and Cenk Misirli," Chapter 11: Mechanical and Metallurgical Properties of Friction Welded Aluminium Joints", World's largest Science, Technology \& Medicine Open Access book publisher, 2013. https://doi.org/10.5772/51130. 